\title{
HUBUNGAN MINAT BELAJAR TERHADAP PRESTASI BELAJAR FISIKA
}

\author{
Leo Charli ${ }^{1}$, Tri Ariani ${ }^{2}$, Lusi Asmara ${ }^{3}$ \\ STKIP-PGRI Lubuklinggau, 1,3 \\ leocharli48@yahoo.com ${ }^{1}$
}

Submit, 03-06-2019 Accepted,30-06-2019 Publish,30-06-2019

\begin{abstract}
: the purpose of this study was to find out the relationship between learning interest in learning achievement in physics of class XI students at Karang Jaya Public High School 2017/2018 Academic Year. The research method used is correlation research. The population is all class students of Karang Jaya High School 2017/2018 Academic Year totaling 103 people and as a sample 1 class is taken, namely the XIA class totaling 26 people. Data collection techniques were carried out by questionnaire technique. The magnitude of the correlation between the two variables tested (rxy) is 0.50 (medium correlation coefficient). The regression equation is $Y=42+0.51 X$. the value of $b$ which is positive, means that interest in learning has a positive effect on student learning achievement. The results of the calculation of linearity test Fcount $=8.11$ while from the $F$ distribution table at the significance level $\alpha$ $=0.05$ where $d b$ re $g$ (b la) 1 and $d b$ res $=26$ this means there is a linear relationship of learning interest with student achievement in physics learning. The results of this study indicate that there is a significant relationship between interest in learning with physics learning achievement of students of Class XI Karang Jaya Public High School 2017/2018 Academic Year. It is expected that students always train themselves to dare to appear in expressing their opinions in public places.
\end{abstract}

Keywords: interest, learning achievement

Abstrak: tujuan penelitian ini adalah untuk mengetahui Hubungan Minat Belajar Terhadap Prestasi Belajar Fisika Siswa Kelas XI SMA Negeri Karang Jaya Tahun Ajaran 2017/2018. Metode penelitian yang digunakan adalah penelitian korelasi. Populasinya adalah seluruh siswa kelas SMA Negeri Karang Jaya Tahun Ajaran 2017/2018 berjumlah 103 orang dan sebagai sampel diambil 1 kelas, yaitu kelas XIA berjumlah 26 orang. Teknik pengumpulan data dilakukan dengan teknik angket. Besarnya korelasi antara kedua variabel yang diuji (rxy) adalah 0,50 (koefisien korelasi sedang). Persamaan regresinya adalah $Y=42+0,51 X$. nilai b yang bertanda positif, berarti minat belajar berpengaruh secara positif terhadap prestasi belajar siswa. Hasil perhitungan uji linieritas nilai $F_{\text {hitung }}=8,11$ sedangkan dari tabel distribusi $F$ pada taraf signifikansi $\alpha=0,05$ dimana $d b$ re $g(b \square a) 1$ dan db res $=$ 26 ini berarti ada hubungan linier minat belajar dengan prestasi belajar siswa dalam pembelajaran fisika. Hasil penelitian ini menunjukkan bahwa ada hubungan yang signifikan antara minat belajar dengan prestasi belajar fisika siswa Kelas XI SMA Negeri Karang Jaya Tahun Ajaran 2017/2018.Diharapkan siswa selalu melatih dirinya untuk berani tampil dalam mengungkapkan pendapatnya di tempat umum.

Kata Kunci : minat, prestasi belajar

\section{PENDAHULUAN}

Pendidikan merupakan sesuatu yang tidak terlepas dan bersifat sangat penting dalam kehidupanmanusia, karena melalui pendidikan akan terbentuk sumber daya manusia yang berkualitas. Salah satu bentuk pendidikan formal adalah pendidikan yangdiselenggarakan di sekolah. Menurut Piaget dalam Sagala (2006) pendidikan berarti menghasilkan dan mencipta, meskipun suatu penciptaan itu dibatasi oleh perbandingan sangat dipengaruhi oleh banyak faktor, salah satunya adalah minat anak dalam belajar. Minat memiliki peranan yang sangat penting dalam kehidupan siswa dan mempunyai dampak yang besar terhadap sikap dan perilaku. Siswa yang berminat terhadap kegiatan pembelajaran akan berusaha lebih keras dibandingkan dalam bentuk kegiatan, siswa bekerja dan mengalami apa yang ada di akan belajar dengan baik sebab 
tidak menarik baginya. Siswa akan malas belajar dan lingkungan tidak Bahan pelajaran yang menarikminat siswa, lebih akan mendapatkan kepuasandaripelajaran itu. secara individu maupun berkelompok.

Minat belajar sangat besar pengaruhnya terhadap hasil belajar, karena apabila bahan pelajaran yang dipelajari tidak sesuai dengan minat, siswa tidak siswa yang kurang berminat dalam belajar. Dalam belajar diperlukan suatu pemusatan perhatian agarapa yang dipelajari dapat dipahami. Dalam meningkatkan minat belajar siswa, proses pembelajaran dapat dilakukand engan penciptaan yang lain, pendidikan sebagai penghubung dua sisi, di satu sisi individu yang sedang tumbuh dan disisi lain nilai sosial, intelektual, dan moral yang akhirnya menjadi tanggung jawabpendidik untuk mendorong individu tersebut. Setiap orangtua yang menyekolahkan anaknya menginginkan anaknya meraih nilai yang baik. Namun untuk mencapai hal itu bukanlah suatu hal yang mudah.

Hal itu dikarenakan keberhasilan belajar mudah dipelajari sehingga dapat meningkatkan hasil belajar. Menurut Djamarah (2006) pendidikan yang paling efektif untuk membangkitkan minat belajar pada siswa adalah dengan menggunakan minat-minat siswa yang telah ada dan membentuk minat-minat baru pada diri siswa. Hal ini dapat dicapai dengan jalan memberikan informasi pada siswa mengenai hubungan antara suatu bahan pengajaran yang akandiberikan dengan bahan pengajaran yang lalu, menguraikan kegunaan bagi siswa dimasa yang akan datang. Minat dapat dibangkitkan dengan cara menghubungkan materi pelajaran dengan suatu berita sensasional yang sudah diketahui kebanyakan siswa. Minat belajar dalam diri siswa harus dipupuk secara terus menerus sehingga akan semakin meningkat didalam diri siswa. Namun, seiring dengan kemajuan teknologi yang semakin pesat dapat mengakibatkan dampak buruk pada minat belajar siswa. Banyak faktor yang dapat menurunkan minat belajar dalam diri siswa seperti, banyaknya jenis hiburan, games, dan tayangan TV yang dapat mengalihkan perhatian siswa dari buku pelajaran.

Dengan minat belajar yang tinggi siswa dapat memperoleh pengetahuan dan wawasan serta hasil belajar yang baik. Dalam pembelajaran guru harus melihat kondisi siswa, karena kondisi siswa sangat penting untuk diperhatikan. Kondisi siswa yang sangat penting adalah bagaimana minatnya dalam mata pelajaran. Siswa yang berminat akan lebih perhatian dan akan lebih ingin tahu terhadap mata pelajaran yang dipelajarinya. Minat yang kuat akan menimbulkan usaha yang gigih dan tidak putus asa dalam menghadapi tantangan.

Berdasarkan wawancara dengan guru kelas XI di SMA Negeri Karang Jaya, didapatkan bahwa hasil belajar fisika siswa kelas XI masih rendah. Hal ini tercermin pada nilai hasil ujian semester ganjil di kelas XI SMA Negeri Karang Jaya tahun ajaran 2016/2017. Dari 25 siswa, siswa yang tuntas 8 siswa jika dipersentasikan $32 \%$ dan yang tidak tuntas 17 orang jika dipersentasikan $68 \%$. Hasil ini masih di bawah kriteria ketuntasan minimal (KKM) yang ditetapkan sekolah yaitu 76. Guru menjelaskan beberapa penyebab hasil belajar siswa rendah adalah karena pada saat guru memberikan penjelasan, siswa kurang memperhatikan.

Hanya ada beberapa siswa yang memperhatikan penjelasan guru. Sementara siswa yang lain memperhatikan obyek lain seperti mengobrol dengan teman semeja, bermain alat tulis, serta tiduran dengan meletakkan kepala di atas meja. Keaktifan siswa saat pembelajaran 
rendah. Hal ini ditunjukkan pada saat guru mengajukan pertanyaan, hanya beberapa siswa yang menjawab pertanyaan guru. Begitu juga saat guru memberikan kesempatan siswa untuk bertanya tidak ada siswa yang mengajukan pertanyaan berkaitan dengan materi pelajaran fisika yang disampaikan guru. berdasarkan wawancara dengan beberapa siswa yang dilakukan peneliti di SMA Negeri Karang Jaya, beberapa diantara mereka mengatakan bahwa mereka tidak menyukai mata pelajaran fisika. Menurut mereka fisika merupakan mata pelajaran yang paling sulit dan dapat membuat pusing. Bahkan menurut mereka mata pelajaran matematika merupakan mata pelajaran yang paling menakutkan. Faktor intern yang mempengaruhi belajar dan hasil belajar salah satunya adalah minat. Beberapa gejala yang telah dipaparkan di atas, yaitu masih rendahnya perhatian dan aktifitas siswa menunjukkan bahwa minat belajar fisika pada siswa kelas XI masih rendah. Cara guru mengajar yang monoton dan kurang bervariasi membuat siswa kurang terlibat dalam aktifitas pembelajaran. Kurangnya siswa terlibat dalam pembelajaran kemudian membuat siswa menaruh perhatian yang rendah pada mata pelajaran fisika. Perhatian yang rendah membuat siswa tidak dapat fokus dalam menerima pesan dan isi materi pembelajaran, yang kemudian berpengaruh pada prestasi belajar siswa pada mata pelajaran fisika. Slameto (2013) menyatakan minat merupakan kecenderungan yang tetap untuk memperhatikan dan mengenang beberapa kegiatan. Ketika seseorang memiliki minat terhadap sesuatu maka ia akan menunjukkan rasa tertarik yang tinggi dengan memperhatikan secara terus-menerus dan disertai dengan perasaan senang. Dimana perasaan senang yang ada, bermuara pada kepuasan. Rasa kecenderungan ini nampak pada perhatian yang lebih banyak pada sesuatu itu, sehingga memungkinkan individu lebih giat mempelajarinya. Dalyono (2005) menyebutkan minat belajar yang besar cenderung menghasilkan prestasi belajar yang tinggi, sebaliknya jika minat belajar kurang maka akan menghasilkan prestasi yang rendah. Minat dapat timbul karena adanya daya tarik dari luar dan juga datang dari hati sanubari. Minat yang besar memudahkan untuk mencapai tujuan yang diminati. Minat belajar dapat timbul disebabkan beberapa hal, antara lain adanya keinginan yang kuat untuk menaikkan atau memperoleh pekerjaan yang baik serta ingin hidup senang dan bahagia. Senada dengan pendapat di atas, Slameto (2013) menyatakan minat belajar memiliki pengaruh yang besar terhadap prestasi belajar, karena jika bahan pelajaran yang dipelajari tidak sesuai dengan minat siswa, siswa tidak akan belajar dengan baik. Jika belajar tanpa disertai minat, siswa akan malas dan tidak akan mendapatkan kepuasan dalam mengikuti pembelajaran. Berdasarkan latar belakang masalah yang telah diuraikan, maka permasalahan dalam penelitian ini yaitu "Hubungan Minat Belajar Terhadap Prestasi Belajar Fisika Siswa Kelas XI SMA Negeri Karang Jaya Tahun Ajaran 2016/2017?".

\section{LANDASAN TEORI \\ Pengertian Belajar}

Menurut Hilgrd dan Bower yang dikutip dan diterjemahkan oleh Purwanto (2003) mengemukakan pengertian belajar sebagai berikut: Belajar berhubungan dengan tingkah laku seseorang terhadap sesuatu situasi tertentu yang disebabkan oleh pengalaman yang berulang-ulang dalam situasi itu, dimana perubahan tingkah laku tidak tidak dapat dijelaskan atau dasar kecenderungan 
respon pembawaan, kematangan, atau keadaan-keadaan sesaat seseorang (misalnya kelelahan, pengaruh obat, dan sebagainya). Menurut Slameto (2013) "Belajar ialah suatu proses usaha yang dilakukan untuk memperoleh suatu perubahan tingkah laku yang baru secara keseluruhan, sebagai hasil pengalamanya sendiri dalam interaksinya dengan lingkunganya".

Dari pendapat ketiga ahli tersebut belajar dapat diartikan sebagai proses yang menghasilkan perubahan yang bersifat menetapdan menyeluruh sebagai hasil dari adanya respon individu terhadap situasi tertentu. Perubahan tersebut tidak hanya berkaitan dengan bertambahnya ilmu pengetahuan, namun juga berwujud keterampilan, kecakapan, sikap, tingkah laku, pola pikir, kepribadian dan lainlain.

\section{Tinjauan Tentang Minat Belajar Siswa}

Pengertian Minat Belajar Untukdapat melihat keberhasilan proses kegiatan pembelajaran, seluruh faktorfakor yang berhubungan dengan guru dan siswa harus dapat diperhatikan. Mulai dari perilaku guru dalam mengajar sampai dengan tingkah laku siswa sebagai timbal balik dari hasil sebuah pengajaran. Tingkah laku siswa ketika mengikuti proses pembelajaran dapat mengindikasikan akan ketertarikan siswa tersebut terhadap pelajaran itu atau sebaliknya. Ketertarikan siswa inilah yang merupakan salah satu tanda-tanda minat.

Menurut Syah (2011), minat adalah kecenderungan dan kegairahan yang tinggi atau keinginan yang besar terhadap sesuatu. Sementara itu Slameto (2010) mengatakan bahwa Minat adalah suatu rasa lebih suka dan rasa ketertarikan pada suatu hal atau aktivitas, tanpa ada yang menyuruh.
Berdasarkan pengertian tersebut dapat disimpulkan bahwa minat akan timbul apabila mendapatkan rangsangan dari luar. Sehingga kecenderungan untuk merasa tertarik pada suatu bidang bersifat menetap dan merasakan perasaan yang senang apabila ia terlibat aktif didalamnya. Meskipun perasaan senang ini timbul dari lingkungan atau berasal dari objek yang menarik.

\section{Indikator Minat Belajar}

Slameto (2003) menyatakan bahwa minat adalah suatu rasa lebih suka dan rasa ketertarikan pada suatu hal atau aktivitas, tanpa ada yang menyuruh.

\section{Rasa Tertarik}

Tertarik adalah merupakan awal dari individu menaruh minat, sehingga seseorang yang menaruh minat akan tertarik terlebih dahulu terhadap sesuatu. Ketertarikan yang dimaksud adalah ketertarikan terhadap pelajaran di kelas.

\section{Perasaan senang}

Perasaan merupakan unsur yang tak kalah penting bagi anak didik terhadap pelajaran yang diajarkan oleh gurunya. Seorang siswa yang memiliki perasaan senang atau suka terhadap suatu mata pelajaran, maka siswa tersebut akan terus mempelajari ilmu yang disenanginya. Tidak ada perasaan terpaksa pada siswa untuk mempelajari bidang tersebut.

\section{Perhatian}

Menurut Gazali dalam Slameto (2013) perhatian adalah keaktifan jiwa yang dipertinggi, jiwa itu pun sematamata tertuju kepada suatu obyek (benda/ hal) atau sekumpulan objek. Untuk dapat menjamin hasil belajar yang

baik, maka siswa harus mempunyai perhatian terhadap bahan yangdipelajarinya, jika bahan pelajaran tidak menjadi perhatian siswa, maka 
timbullah kebosanan, sehingga ia tidak lagi suka belajar.

Aktivitas yang disertai dengan perhatian intensif akan lebih sukses dan prestasinya pun akan lebih tinggi. Maka dari itu sebagai seorang guru harus selalu berusaha untuk menarik perhatian anak didiknya sehingga mereka mempunyai minat terhadap pelajaran yang diajarkan. Siswa yang menaruh minat pada suatu mata pelajaran akan memberikan perhatian yang besar. Ia akan menghabiskan banyak waktu dan tenaga untuk belajar mata pelajaran yang diminatinya. Siswa tersebut pasti akan berusaha keras untuk memperoleh nilai yang bagus yaitu dengan belajar.

\section{Partisipasi}

Partisipasi adalah merupakan keikutsertaan siswa dalam proses pembelajaran. Siswa yang mempunyai minat terhadap suatu pelajaran akan melibatkan dirinya dan berpartisipasi aktif dalam hal- hal yang berkaitan dengan kegiatan pembelajaran yang diminatinya. Partisipasi siswa dalam proses pembelajaran bisa dilihat dari sikap siswa yang partisipatif. Siswa rajin bertanya dan mengemukakan pendapatnya. Selain itu siswa selalu berusaha terlibat atau mengambil andil dalam setiap kegiatan.

\section{METODE PENELITIAN}

Penelitian ini merupakan penelitian ex-post facto, karena dalam penelitian ini tidak dibuat perlakuan atau manipulasi terhadap variabelvariabelnya, tetapi hanya mengungkap fakta berdasarkan gejala yang telah ada pada diri responden. Analisis dalam penelitian ini menggunakan analisi statistic yaitu menggunakan angkaangka untuk menyimpulkan hasil penelitian.

$$
\text { Penelitian menggunakan }
$$

rancangan penelitian dengan jenis penelitian korelasi. Penelitian korelasi adalah penelitian yang bertujuan untuk mengetahui hubungan atau pengaruh antara variabel dengan variabel yang lain.

\section{HASIL PENELITIAN \\ Data Hasil Belajar Fisika}

Data hasil belajar fisikadiperoleh melalui dokumentasi hasil nilai tes Ujian Akhir Semester (UAS) semestar genap mata pelajaran fisika pada guru mata pelajaran. Dari data tersebut menunjukkan bahwa semua nilai siswa memenuhi Kriteria Ketuntasan Minimum (KKM) kelas XI yaitu 76, dengan nilai rata-rata 84,32 . Sedangkan simpangan Baku nya 4,42.

\section{Data Minat Belajar}

Data minat belajar siswa pada mata pelajaran fisika diperoleh melalui angket yang disebar ke dalam 25 butir pertanyaan, dibagiankan pada 25 orang siswa yang dijadikan sebagai sampel. Berikut tabel hasil rekapitulasi análisis ketercapaian angket minat belajar siswa.

Siswa secara keseluruhan di dapat bahwa rata-rata minat belajar fisika siswa kelas XI SMA Negeri Karang Jaya Tahun Ajaran 2016/2017 berada pada kategori sedang dengan rata-rata 81,72 . Sedangkan simpangan baku nya 19,02 .

\section{Koefisien Determinasi (KD) Uji Linieritas}

Jadi koefisien determinasi antara minat belajar terhadap hasil belajar siswa adalah 25\%. Hal ini dapat diartikan bahwa minat belajar memberikan kontribusi yang positif terhadap hasil belajar fisika sebesar $25 \%$.

\section{Persamaan Regresi Linier Sederhana}

Untuk mengetahui apakah naik atau menurunnya variabel dependen (hasil belajar) dapat dilakukan melalui 
peningkatan atau penurunan variabel dependen (minat belajar) dengan menggunakan persamaan regresi linier sederhana. Hasil perhitungan Regresi antara skor hasil angket minat belajar dengan hasil belajar siswa, menghasilkan nilai $a=46$ dan $\mathrm{b}=0,48$, sehingga persamaan regresinya adalah $\mathrm{Y}=46+0,48 \mathrm{X}$. nilai $\mathrm{b}$ yang bertanda positif, berarti minat belajar berpengaruh secara positif terhadap prestasi belajar siswa. Untuk setiap kenaikan/penurunan skor minat belajar sebesar satu akan diikuti dengan kenaikan/penurunan skor hasil belajar sebesar 0,48. Untuk mengetahui hubungan linear antara minati belajar siswa dengan hasil belajar siswa menggunakann perhitungan uji linieritas. Perhitungan uji linieritas adalah nilai $F_{\text {hitung }}=7,05>4,20=F$ tabelini berarti ada hubunganlinier minat belajar dengan hasil belajar siswa dalam pembelajaran fisika. Berdasarkan hasil perhitungan uji linieritas nilai $F_{\text {hitung }}=$ 7,05 sedangkan dari tabel distribusi $\mathrm{F}$ pada taraf signifikansi $\alpha=0,05$ dimana $\mathrm{db}$ re $g(b \square a)=1$ dan $\mathrm{db}$ res $=25$. Karena $F_{\text {hitung }}=7,05>4,20=F_{\text {tabel }}$ ini berarti ada hubunganlinier minat belajar dengan prestasi belajar siswa dalam pembelajaran fisika.

\section{PEMBAHASAN}

Penelitian ini dilakukan di kelas XI SMA Negeri Karang Jaya Tahun Ajaran 2016/2017 dengan tujuan untuk mengetahui hubungan minat belajar siswa terhadap prestasi belajar fisika siswa. Rasa ketertarikan siswa terhadap mata pelajaran tertentu merupakan salah satu ciri bahwa siswa memiliki minat dalam mata pelajaran tersebut. Rasa ketertarikan ini akan membuat siswa merasa senang terhadap mata pelajaran tersebut. Fungsi minat sangat besar dalam mencapai hasil belajar siswa. Mulai dari keinginan untuk melakukan aktivitas dilakukan sampai akhirnya mencapai tujuan yang diharapkan bagi siswa maupun bagi orang tua siswa. Jika siswa mempunyai minat belajar yang kuat maka diharapkan belajar siswa akan baik.

Hasil angket mengenai minat dari pernyataan positif diketahui bahwa siswa telah mempunyai sifat inisiatif dalam pembelajaran fisika, semangat belajar siswa belum maksimal, keinginan belajar terlihat kuat dimana siswa memiliki keingintahuan melalui belajar sendiri, siswa telah dapat mencari jalan keluar memecahkan persoalan dalam memahami materi yang dihadapi, dan sikap belajar siswa yang tinggi.

Berdasarkan data hasil penelitian yang berhasil dikumpulkan, maka akan diteliti apakah ada hubungan antara variabel bebas yaitu minat belajar dengan variabel terikat yaitu hasil belajar Fisika (Y). Dari data yang dikumpulkan tersebut kemudian dianalisis dan dilakukan pembahasan mengenai hasil penelitian. Fungsi minat sangat besar dalam mencapai hasil belajar siswa. Mulai dari keinginan untuk melakukan aktivitas dilakukan sampai akhirnya mencapai tujuan yang diharapkan bagi siswa maupun bagi orang tua siswa. Jika siswa mempunyai minat belajar yang kuat maka diharapkan belajar siswa akan baik.

Hasil angket mengenai minat dari pernyataan positif diketahui bahwa siswa telah mempunyai sifat inisiatif dalam pembelajaran fisika, semangat belajar siswa belum maksimal, keinginan belajar terlihat kuat dimana siswa memiliki keingintahuan melalui belajar sendiri, siswa telah dapat mencari jalan keluar memecahkan persoalan dalam memahami materi yang dihadapi, dan sikap belajar siswa yang tinggi.

Pada sisi negatif mengenai minati berdasarkan angket terlihat bahwa masih adanya siswa yang tidak 
bersemangat dalam mengikuti pembelajaran, ada beberapa siswa yang tidak memiliki keingintahuan mengenai masalah belajar yang dihadapinya dan masih ada siswa yang tidak ingin mencari jalan keluar dalam menghadapi kesulitan, serta masih ada beberapa siswa yang tidak bersemangat dalam mengikuti pembelajaran. Pada sisi negatif mengenai minat berdasarkan angket terlihat bahwa masih adanya siswa yang tidak bersemangat dalam mengikuti pembelajaran, ada beberapa siswa yang tidak memiliki keingintahuan mengenai masalah belajar yang dihadapinya dan masih ada siswa yang tidak ingin mencari jalan keluar dalam menghadapi kesulitan, serta masih ada beberapa siswa yang tidak bersemangat dalam mengikuti pembelajaran.

Besarnya korelasi antara kedua variabel yang diuji (rxy) adalah 0,93 (koefisien korelasi sangat kuat). Nilai tersebut menunjukkan bahwa antara variabel minat belajar dengan variabel hasil belajar pada mata pelajaran fisika memiliki korelasi positif. Dengan melihat harga $r$ tersebut maka dapat diinterprestasikan bahwa korelasi tersebut sangat tinggi. Dengan demikian dapat disimpulkan bahwa terdapat korelasi signifikan dan positif antara minat belajar denganhasil belajar pada mata pelajaran Fisika siswa kelas XI XI SMA Negeri Karang Jaya Tahun Ajaran 2016/2017. Sehingga dapat disimpulkan bahwa antara minat belajar dengan hasil siswa MA Mazro'illah Lubuklinggau. Koefisien determinasi antara motivasi belajar terhadap hasil belajar siswa adalah $86 \%$.

Hal ini dapat diartikan bahwa minat belajar memberikan kontribusi yang positif terhadap hasil belajar fisika sebesar $86 \%$ sedangkan $14 \%$ ditentukan oleh pihak lain yang tidak diteliti. Regresi antara skor hasil angket motivasi belajar dengan nilai belajar siswa, menghasilkan nilai $a=46$ dan $\mathrm{b}=$ 0,48 , sehingga persamaan regresinya adalah $\mathrm{Y}=46+0,48 \mathrm{X}$. nilai $\mathrm{b}$ yang bertanda positif, berarti minat belajar dengan kenaikan/penurunan skor hasil belajar sebesar 0,48. Hubungan linear antara minat belajar siswa dengan minat belajar siswa menggunakann perhitungan uji linieritas. Hasil perhitungan uji linieritas nilai $=\quad 7,05$ sedangkan dari tabel distribusi $\mathrm{F}$ pada taraf signifikansi $\alpha=0,05$ dimana $\mathrm{db}$ re $g(b \square a)=1 \mathrm{dan} \mathrm{db}$ res $=24$. Karena $F$ hitung $=7,05>4,20=F_{\text {tabel }}$ ini berarti ada hubunganlinier minat belajar dengan hasil belajar siswa dalam pembelajaran fisika.

Hasil penelitian ini menunjukkan adanya hubungan yang signifikan dari minatbelajar terhadap hasil belajar fisika dengan koefisien korelasi $r=0,48$. Dengan melihat harga $r$ tersebut maka dapat diinterprestasikan bahwa korelasi tersebut sedang. Hasil penelitian ini menunjukkan bahwa jika siswa mempunyai minat yang tinggi terhadap mata pelajaran fisika, maka hasil belajar fisika nya akan lebih tinggi.

Dengan kata lain, untuk mendapatkan hasil belajar fisika yang tinggi dapat ditempuh dengan cara meningkatkan minat belajar terhadap mata pelajaran Fisika. Hal itu dapat dimengerti apabila minat belajar terhadap mata pelajaran fisika positif atau tidak maka ia akan mudah menyesuaikan diri terhadap mata pelajaran fiiska sehingga hasil Belajar fisika tinggi. Besarnya pengaruh minat belajar dengan hasil belajar fisika adalah $23,04 \%$.

Jadi hipotesis yang diajukan oleh peneliti dapat diterima kebenarannya pada taraf kepercayaan 5\%. Sehingga peneliti menyimpulkan bahwa ada hubungan yang signifikan antara minat belajar terhadap hasil belajar fisika. Tetapi minat belajar bukan syarat yang mutlak untuk mengoptimalkan hasil 
belajar fisika karena dimungkinkan ada faktor-faktor lain yang mempengaruhi hasil belajar fisika diluar penelitian ini, misalnya model pembelajaran, bakat, intelegensi kemampuan siswa dan sebagainya.

Selain minat belajar, model pembelajaran juga mempengaruhi hasil belajar fisika. Hal ini ditunjukkan dengan berbagai hasil penelitian berikut ini. Hasil penelitian yang di lakukan oleh Gumay (2017), menyimpulkan bahwa terdapat perbedaan hasil belajar fisika antara kelas yang diajarkan dengan model pembelajaran Two Stay Two Stray dan kelas yang diajar kan dengan metode ceramah dan tanya jawab dikelas VIII SMP Negeri 3 Lubuklinggau Tahun Pelajaran $2015 / 2016$. Penelitian yang dilakukan oleh Lovisia (2017), disimpulkan bahwa hasil belajar fisika siswa kelas $\mathrm{X}$ SMA Negeri 2 Lubuklinggau setelah diterapkan Model Make a Macth secara signifikan dinyatakan tuntas.

Kesimpulan penelitian yang dilakukan oleh Gumay, et all (2018) bahwa ada pengaruh yang signifikan Metode Demonstrasi terhadap Hasil Belajar Fisika kelas X Ma Al-Muhajirin Tugumulyo tahun 2016/2017. Penelitian yang dilakukan oleh Khotimah, et all (2018) menyimpulkan bahwa hasil belajar siswa dengan mengunakan model pembelajarn Quantum Teaching signifikan tuntas. Aktivitas belajar siswa dalam proses pembelajaran dalam kategori aktif. Sedangkan respon siswa setelah mengikuti pembelajaran dalam kategori baik.

Penelitian yang dilakukan oleh Amin, et all (2018), disimpulkan, hasil belajar fisika dengan menggunakan model pembelajaran kooperatif tipe jigsaw lebih tinggi dibandingkan dengan model pembelajaran konvensional. Penelitian yang dilakukan oleh Lovisia (2018), disimpulkan bahwa ada pengaruh yang signifikan model pembelajaran inkuiri terbimbing terhadap hasil belajar Fisika Siswa Kelas X SMAN 6 Lubuklinggau.

Penelitian yang dilakukan oleh Charli, et all (2018), menyimpulkan bahwa penerapan model think pair share sangatlah tepat dalam pembelajaran fisika. Berdasarkan hasil penelitian yang telah dilakukan di atas, maka dapat disimpulkan bahwa model pembelajaran juga mempengaruhi dalam hasil belajar siswa.

\section{SIMPULAN}

Berdasarkan hasil penelitian dan pembahasannya, maka dapat disimpulkan bahwa ada hubungan yang signifikan antara minat belajar dengan prestasi belajar fisika siswa kelas XI SMA Negeri Karang Jaya tahun ajaran 2016/2017. Hasil perhitungan uji linieritas nilai $F_{\text {hitung }}=7,05$ sedangkan dari tabel distribusi $F$ pada taraf kepercayaan $5 \%$. Selain minat belajar, faktor-faktor lain yang mempengaruhi hasil belajar fisika diluar penelitian ini, misalnya model pembelajaran, bakat, intelegensi kemampuan siswa dan sebagainya.

\section{DAFTAR PUSTAKA}

Amin, A., Charli, L., \& Fita, W. N. (2018). Pengaruh Model Pembelajaran Kooperatif Tipe Jigsaw dan Konvesional terhadap Hasil Belajar Fisika. Science and Physics Education Journal (SPEJ), 2(1), 11-17. doi:10.31539/spej.v2i1.424

Bahri Djamarah, Syaiful. (2006). Guru dan Anak Didik dalam Interaksi Edukatif. Jakarta: Rineka Cipta

Charli, L., Amin, A., \& Pujiastuti, I. (2018). Penerapan Model Think Pair Share pada Pembelajaran Fisika. Journal of Education and Instruction (JOEAI), 1(2), 74-80. 
https://doi.org/https://doi.org/10.3 1539/joeai.v1i2.396

Dalyono M. (2005).Psikologi

Pendidikan. Jakarta: PT

Rineka Cipta.

Gumay, O. P. U. (2017). Pengaruh Model Pembelajaran Kooperatif Tipe Two Stay Two Stray terhadap Hasil Belajar Fisika Siswa Kelas 8 SMP Negeri 3 Lubuklinggau. Science and Physics Education Journal (SPEJ), 1(1), 49-58. doi:10.31539/spej.v1i1.102

Gumay, O. P. U., \& Bertiana, V. (2018). Pengaruh Metode Demonstrasi terhadap Hasil Belajar Fisika Kelas X MA Almuhajirin Tugumulyo. Science and Physics Education Journal (SPEJ), 1(2), 96-102. doi:10.31539/spej.v1i2.272

Khotimah, U. K., Ariani, T., \& Gumay, O. P. U. (2018). Efektivitas Model Pembelajaran Quantum Teaching terhadap Hasil Belajar Fisika Siswa SMA Negeri Jayaloka. Science and Physics Education Journal (SPEJ), 1(2), 103-110. doi:10.31539/spej.v1i2.255

Lovisia, E. (2017). Penerapan Model Make A Match pada Pembelajaran Fisika Kelas X Sma Negeri 2 Kota Lubuklinggau. Science and Physics Education Journal (SPEJ), 1(1), 7-22. doi:10.31539/spej.v1i1.58

Lovisia, E. (2018). Pengaruh Model Pembelajaran Inkuiri Terbimbing terhadap Hasil Belajar. Science and Physics Education Journal (SPEJ), 2(1), 1-10. doi:10.31539/spej.v2i1.333

Nursid, Sumaatmadja. (2001). Studi IPA Terpadu Suatu Pendekatan dan Analisa Keruangan. Bandung: Alumni
Purwanto, Ngalim. (2003). Psikologi Pendidikan. Bandung: PT Remaja Rosdakarya

Syaiful, Sagala. (2006). Konsep dan Makna Pembelajaran. Bandung: Alfabeta

Slameto. (2013). Belajar dan FaktorFaktor yang Mempengaruhinya. Jakarta:PT Bina aksara

Syah, Muhibbin. (2011).Psikologi Pendidikan dengan Pendekatan Baru. Bandung: Remaja Rosdakarya 